\title{
Response of established forages on reclaimed mined land to fertilizer $\mathbf{N}$ and $\mathbf{P}$
}

\author{
J.D. REEDER AND W.J. MCGINNIES
}

\section{Abstract}

A field study was conducted from 1981 through 1986 on an established stand of grass and legume species on topsoiled coalmine spoils in northwest Colorado to evaluate the effects of $\mathrm{N}$ and $P$ fertilization on dry matter production, species composition, canopy cover, and forage crude protein and $\mathbf{P}$ concentrations. Fertilizer treatments included annual fall applications in 1981

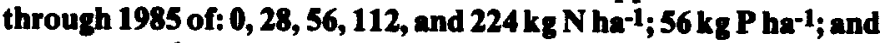
$112 \mathrm{~kg} \mathrm{~N}$ ha-1 $+56 \mathrm{~kg} P \mathrm{ha}^{-1}$. Additionally, single fall applications of $\mathrm{N}$ were applied in 1981 through 1983 at rates of $0,28,56,112$, 224 , and $448 \mathrm{~kg} \mathrm{~N} \mathrm{ha-1} \mathrm{to} \mathrm{other} \mathrm{plots} \mathrm{that} \mathrm{had} \mathrm{not} \mathrm{been} \mathrm{previously}$ fertilized. Plots were harvested at grass anthesis in 1982 through 1986. Fertilizer $P$ significantly increased forage $P$ concentration but did not significantly affect yield, crude protein concentration, or species composition. Fertilizer $\mathbf{N}$ did not significantly affect species composition or forage $P$ concentration but did significantly increase dry matter production and crude protein concentration with increased $\mathbf{N}$ rate. Averaged over the 5 years of the study, annual application of 28, 56, 112, and $224 \mathrm{~kg} N \mathrm{Na}^{-1}$ increased herbage production by $23,19,19$, and $11 \mathrm{~kg}$ per $\mathrm{kg} \mathrm{N}$ applied, respectively. On those plots receiving a single application of fertilizer $\mathbf{N}$, significant increases in dry matter production with increased $\mathbf{N}$ rate were noted only during the first growing season after $\mathbf{N}$ fertilization. Significant yield response to carry-over fertilizer $\mathbf{N}$ was noted in the second (and occasionally third) growing seasons only at the $448 \mathrm{~kg} \mathrm{~N}^{\mathrm{Na}} \mathrm{N}^{-1}$ rate. The data indicate that annual applications of fertilizer $\mathbf{N}$ would be more effective than infrequent applications of high rates of $\mathbf{N}$ on these reclaimed mined lands.

\section{Key Words: fertilization, botanical composition, forage yield}

The deficiency of plant-available nitrogen $(\mathrm{N})$ is a common limitation to successful revegetation and long-term stability of lands disturbed by surface mining (Reeder and Sabey 1987). Nitrogen deficiency seldom limits seedling establishment on reclaimed mined land (Cook et al. 1974, Woodmansee et al. 1978, McGinnies and Crofts 1986). However, $N$ deficiency can affect the long-term stability of a site since some plant communities fail to persist on $\mathrm{N}$-deficient sites, despite initial seedling establishment and fertilization (Reeder and Sabey 1987). Depending on its depth and quality, replaced topsoil can ameliorate $\mathrm{N}$ deficiencies by providing mineralizable organic $\mathbf{N}$. Both herbage and root production have been found to increase with increasing depth of topsoil (McGinnies and Nicholas 1980, Redente and Hargis 1985). However, topsoil of sufficient depth and quality to alleviate $\mathrm{N}$ deficiencies is not always available, and supplemental fertilizer $\mathbf{N}$ may be needed a number of years after stand establishment.

Numerous studies have reported that availability of $\mathbf{N}$ limits grassland production (McGinnies 1968; Power and Alessi 1970, 1971, Wight 1976, Wight and Black 1979, and Power 1980a), and other studies report that availability of water primarily regulates response to $\mathrm{N}$ fertilzer (Colville et al. 1963, Smika et al. 1965, Johnston et al. 1969, Power 1980b). The question arises as to

\footnotetext{
Authors are soil scientist and range scientist (retired), USDA-ARS, P.O. Box E, Fort Collins, Colo. 80522. In cooperation with Colorado State University and the Colorado Yampa Coal Corp., Steamboat Springs, Colorado.

Manuscript accepted 5 December 1988.
}

whether $\mathbf{N}$ applied in 1 large application could be stored for long periods in the soil and be available for plant use in times of adequate water. Single applications would be advantageous in terms of reduced handling and labor costs. Studies by Power and Alessi (1971) and Power (1967) suggest that single applications of high rates of $\mathrm{N}$ fertilizer to nondisturbed semiarid grasslands could develop a pool of available $\mathbf{N}$ that plants could use whenever water is not limiting. However, the effectiveness of single applications of high rates of $\mathbf{N}$ fertilizer has not been adequately tested for mined lands.

Studies have been conducted to evaluate the effects of fertilizer on establishment and development of seeded plants on disturbed lands (DePuit and Coenenberg 1979; Doerr et al. 1983; Redente et al. 1984). However, little is known about the effects of $\mathrm{N}$ fertilizer rate and frequency on reclaimed mined lands that have an established stand ( $>5$ years) of vegetation. Moreover, limited information is available concerning optimum fertilizer rates or residual effects on reclaimed mined lands in the central Rocky Mountain region. This study was conducted to evaluate the effects of rate and frequency of $\mathbf{N}$ and $\mathbf{P}$ fertilizer on dry matter production, forage quality, canopy cover, and species composition of an established stand of grass and legume species on topsoiled coal mine spoils.

\section{Methods}

The study was conducted at Energy Mine No. 3 of the Colorado Yampa Coal Company located $32 \mathrm{~km}$ southwest of Steamboat Springs, Colorado. Elevation was $2,100 \mathrm{~m}$ and average annual precipitation was $430 \mathrm{~mm}$. Coal had been strip-mined from the area prior to 1976. Spoils were a mixture of shales and sandstones from the Williams Fork Formation of the Upper Cretaceous Mesa Verde group. In October, 1976, the study area was topsoiled to a depth of 20 to $30 \mathrm{~cm}$ with a heterogeneous mixture of the A and B horizons of a Routt loam (fine montmorillonitic Typic Argiboroll).

Following placement of the topsoil, the area was seeded in October, 1976, with a mixture of plant species consisting of: $5.62 \mathrm{~kg}$ $\mathrm{ha}^{-1}$ smooth brome (Bromus inermis L.), $6.74 \mathrm{~kg} \mathrm{ha}^{-1}$ intermediate wheatgrass (Elytrigia intermedia (Host) Nevski), $3.37 \mathrm{~kg} \mathrm{ha}^{-1}$ western wheatgrass (Pascopyrum smithii (Rydb.) Love), $2.25 \mathrm{~kg} \mathrm{ha}^{-1}$ crested wheatgrass (Agropyron desertorum (Fisch. ex Link) Schult.), $1.12 \mathrm{~kg} \mathrm{ha}^{-1}$ hard fescue (Festuca ovina duriuscula L.), $1.12 \mathrm{~kg} \mathrm{ha}^{-1}$ Kentucky bluegrass (Poa pratensis L.), and $0.56 \mathrm{~kg}$ $\mathrm{ha}^{-1}$ alfalfa (Medicago sativa $\mathrm{L}$.). The initial stand of vegetation was good and grazing was prohibited. At the beginning of this study in 1981, species composition (as estimated from visual determinations of canopy cover) was approximately $50 \%$ smooth brome, $40 \%$ intermediate wheatgrass, and $10 \%$ all other.

Fertilized plots, $5 \times 5 \mathrm{~m}$, were established in September 1981. Plots were arranged in a randomized complete block design with 3 replications. Vegetation was mowed with a rotary mower to a $5.0-$ $7.5 \mathrm{~cm}$ height and the various fertilizer treatments were broadcast onto the soil surface. The fertilizer treatments included annual fall (early October) applications in 1981 through 1985 at the following rates: $0,28,56,112$, and $224 \mathrm{~kg} \mathrm{~N}^{-1} ; 56 \mathrm{~kg} \mathrm{P} \mathrm{ha}^{-1}$; and $112 \mathrm{~kg} \mathrm{~N}$ $\mathrm{ha}^{-1}+56 \mathrm{~kg} \mathrm{P} \mathrm{ha}^{-1}$. Nitrogen was applied as ammonium nitrate and 
$P$ as treble superphosphate. Additionally, single application treatments at rates of $0,28,56,112,224$, and $448 \mathrm{~kg} \mathrm{~N} \mathrm{ha}^{-1}$ were broadcast in October 1981, 1982, and 1983 onto other plots that had not been previously fertilized.

Stands were evaluated in mid-July from 1982 through 1986 when the grasses were at anthesis. Canopy cover was visually determined, always by the same person, within five, $0.21-\mathrm{m}^{2}$ areas selected randomly within each plot, and species composition was estimated from the cover data (Cook and Bonham 1977). A forage sample from a $8.5 \mathrm{~m}^{2}$ area of each plot was harvested with a rotary mower to a $5.0-7.5 \mathrm{~cm}$ height and weighed to determine yield. Subsamples of the mowed vegetation were oven-dried at $60^{\circ} \mathrm{C}$ to determine dry matter production. After vegetation was sampled, all remaining vegetation within the plots was mowed to a 5.0-7.5 $\mathrm{cm}$ height and removed from the plots so that plant samples taken in subsequent years represented the current year's production. Nitrogen and $\mathbf{P}$ concentrations were determined colorimetrically on plant samples ground to $\mathbf{4 0}$ mesh and digested using a modified Kjeldahl-peroxide digestion procedure.

Data were evaluated by analyses of variance and regression analysis. Tukey's $Q$ Test was used where appropriate to evaluate significant differences among treatment means. All differences mentioned in this paper are significant at the $P<0.05$ level.

\section{Results and Discussion}

Physical and chemical properties of the topsoil and spoil are given in Table 1. The data indicate that plant growth at the research site is limited by nutrient deficiencies but not by toxicities. Neither material is saline nor sodic. The level of bicarbonate $\mathbf{P}$ in the topsoil indicates an adequate level of plant-available $P$, while the level in the spoil is considered deficient for plant growth (Olsen and Sommers 1982). Both topsoil and spoil contain relatively low levels of organic $\mathbf{N}$ and organic $\mathrm{C}$. The organic matter concentration of the spoil material is comparable to that of the topsoil, but the spoil organic matter is considerably less susceptible to microbial decomposition and its potential for supplying plant-available $\mathrm{N}$ is very low (Reeder 1988). Although texturally classified as a clay loam (Table 1), the water holding capacity and the cation exchange capacity of the spoil material are low and more closely resemble those of a sandy loam (Donahue et al. 1983).

Table 1. Average physical and chemical characteristics of the topsoil and spoil materials sampled from the nonfertilized control plots at the end of this study.

\begin{tabular}{|c|c|c|}
\hline & Topsoil & Spoil \\
\hline Textural Class & Clay & Clay loam \\
\hline pH & 7.3 & 7.9 \\
\hline Electrical Conductivity (EC) (dS/m) & 0.3 & 2.2 \\
\hline Sodium Adsorption Ratio (SAR) & 0.3 & 0.3 \\
\hline Water Content at $0.033 \mathrm{MPa}(\%, \mathrm{~g} / \mathrm{g})$ & 20.6 & 15.4 \\
\hline Cation Exchange Capacity (cmol/ $/ \mathrm{kg})$ & 34.8 & 11.0 \\
\hline Kjeldahl-N (mg/kg) & 1290 & 1150 \\
\hline $\mathrm{NH}_{4}-\mathrm{N}(\mathrm{mg} / \mathrm{kg})$ & 1.3 & 6.1 \\
\hline $\mathrm{NO}_{3}-\mathrm{N}(\mathrm{mg} / \mathbf{k g})$ & 3.1 & 4.8 \\
\hline Total C $(\mathrm{g} / \mathrm{kg})$ & 19.8 & 21.3 \\
\hline $\mathrm{CO}_{3}-\mathrm{C}(\mathrm{g} / \mathrm{kg})$ & 1.1 & 5.5 \\
\hline Total P (mg/kg) & 597 & 937 \\
\hline Bicarbonate $\mathrm{P}(\mathrm{mg} / \mathrm{kg})$ & 13.5 & 1.8 \\
\hline
\end{tabular}

\section{Forage Yield}

Dry matter production on plots receiving no fertilizer averaged $1,040 \mathrm{~kg} \mathrm{ha}^{-1}$ over 1982 through 1986 , and ranged from $720 \mathrm{~kg} \mathrm{ha}^{-1}$ in 1982 to $1,304 \mathrm{~kg} \mathrm{ha}^{-1}$ in 1984 . For release of bond under current regulations, mining companies must show that dry matter production and aerial cover on reclaimed mined lands are comparable
Table 2. Dry matter production (Y) as related to nitrogen fertilization rate (X) on those plots receiving annual applications of $0-224 \mathrm{~kg} \mathrm{ha}^{-1}$ fertilizer $\mathbf{N}$.

\begin{tabular}{lll}
\hline \hline Year & Quadratic regression equations & $\mathbf{R}^{2}$ \\
\hline 1982 & $\mathrm{Y}=643+14.55 \mathrm{X}-0.039 \mathrm{X}^{2}$ & 0.82 \\
1983 & $\mathrm{Y}=1123+26.02 \mathrm{X}-0.054 \mathrm{X}^{2}$ & 0.84 \\
1984 & $\mathrm{Y}=1147+42.35 \mathrm{X}-0.135 \mathrm{X}^{2}$ & 0.82 \\
1985 & $\mathrm{Y}=688+27.80 \mathrm{X}-0.076 \mathrm{X}^{2}$ & 0.85 \\
1986 & $\mathrm{Y}=957+23.37 \mathrm{X}-0.070 \mathrm{X}^{2}$ & 0.82 \\
\hline
\end{tabular}

to those on a non-mined reference area. A comparison made in 1982 revealed that dry matter production on the non-fertilized study plots was significantly lower than dry matter production on the non-mined reference area. The non-mined reference area averaged $1,350 \mathrm{~kg} \mathrm{ha}^{-1}$ in 1982 and consisted of $31 \%$ grasses, $17 \%$ forbs, and $52 \%$ shrubs (primarily big sagebrush) (Colorado Yampa Coal Company data, 1987 personal communication). In comparison, dry material production on the non-fertilized research plots averaged $720 \mathrm{~kg} \mathrm{ha}^{-1}$ and consisted of $>99 \%$ grasses and $<1 \%$ forbs and alfalfa.

The application of $\mathbf{P}$ did not significantly affect dry matter production in any of the 5 years of this study. Other studies have reported similar results (Lutwick and Smith 1977, Rauzi 1979, Read and Winkleman 1982, Halvorson and Bauer 1984, Redente and Hargis 1985). Wight and Black (1979) reported that P fertilization did not significantly increase yields on a mixed prairie range in eastern Montana except when $\mathbf{N}$ was nonlimiting. They found no yield response to $P$ when applied with $112 \mathrm{~kg} \mathrm{~N} \mathrm{ha}^{-1}$, but a significant yield response when applied with 336 or $1,008 \mathrm{~kg} \mathrm{~N} \mathrm{ha}^{-1}$. In our study, the failure of $P$ to increase production in those plots annually receiving $112 \mathrm{~kg} \mathrm{~N} \mathrm{ha}^{-1}$ plus $56 \mathrm{~kg} \mathrm{Pha}^{-1}$, as compared to

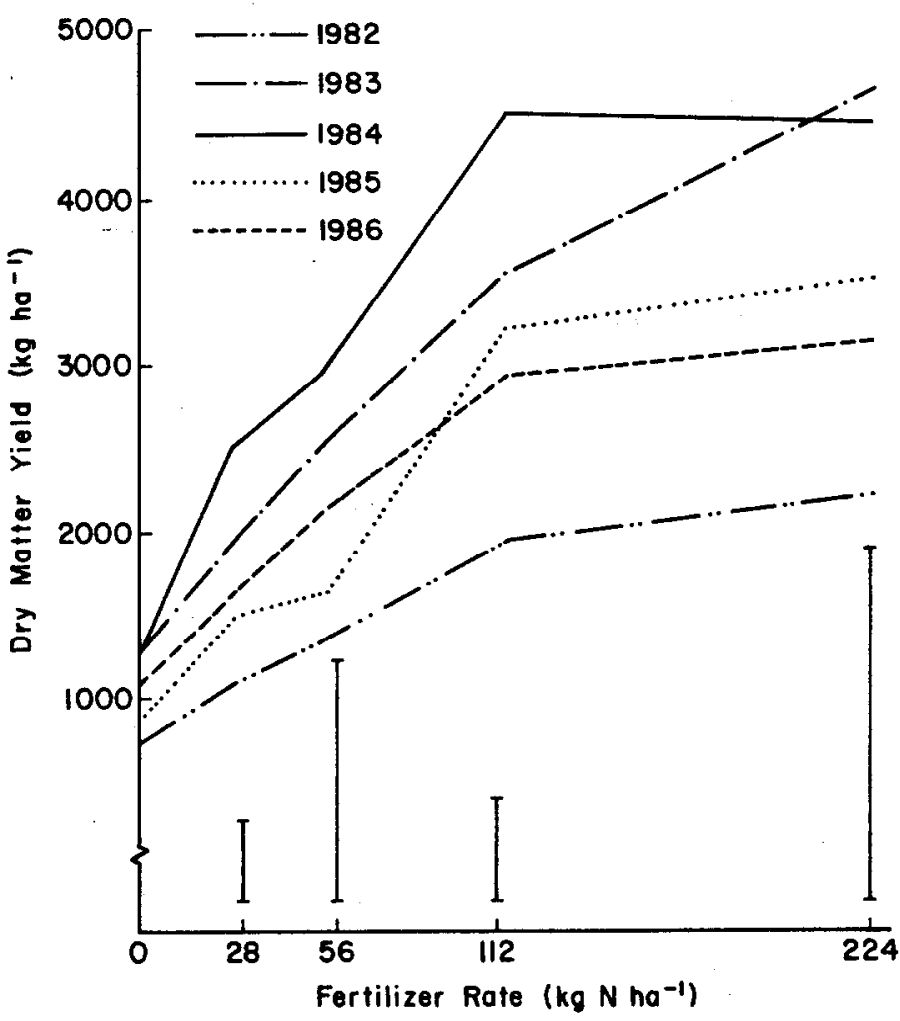

Fig. 1. Annual dry matter production as affected by annual applications of $0,28,56,112$, and $224 \mathrm{~kg} \mathrm{~N} \mathrm{hal} \mathrm{fertilizer.} \mathrm{Error} \mathrm{bars} \mathrm{for} \mathrm{each} N$ rate indicate the least significant difference (according to Tukey's $Q$ test) in dry matter production among years. 
those plots annually receiving only $112 \mathrm{~kg} \mathrm{~N} \mathrm{ha}^{-1}$, suggests that at $112 \mathrm{~kg} \mathrm{~N} \mathrm{ha}^{-1}, \mathrm{~N}$ was still the growth-limiting factor.

On those plots receiving annual applications of $\mathrm{N}$, the increase in dry matter production with increase in annual $\mathbf{N}$ rate was best described with quadratic regression equations for each of the 5 years of this study (Table 2). These equations demonstrate that as the rate of applied $\mathrm{N}$ increased, the dry matter production per unit of applied $\mathrm{N}$ decreased. Averaged over the 5 years of the study, annual application of $28,56,112$, and $224 \mathrm{~kg} \mathrm{~N} \mathrm{ha}{ }^{-1}$ increased herbage production by $23,19,19$, and $11 \mathrm{~kg}$ per $\mathrm{kg} \mathrm{N}$ applied, respectively. Dry matter production varied significantly from year to year, ranging from $1,102-2,532 \mathrm{~kg} \mathrm{ha}^{-1}$ on plots receiving $28 \mathrm{~kg}$ $\mathrm{N} \mathrm{ha}{ }^{-1}$, to $2,250-4,650 \mathrm{~kg} \mathrm{ha}^{-1}$ on plots receiving $224 \mathrm{~kg} \mathrm{~N}^{-1}$ annually (Fig. 1). Annual variations in both precipitation and temperature may be largely responsible for the annual variations in yield response to fertilizer $\mathbf{N}$ found during the 5 years of this study (McGinnies 1968, Power 1986). Leaching losses of fertilizer N below the rooting zone may also have affected yield responses to $\mathrm{N}$ application. Leaching losses of fertilizer ${ }^{15} \mathrm{~N}$ have been measured in studies conducted on these topsoiled spoil materials (Reeder, unpublished data), and are thought to be due in part to the lower water holding capacity of the spoil material (Table 1).

Single applications of fertilizer $N$ ranging from 28 to $448 \mathrm{~kg} \mathrm{ha}^{-1}$ (applied in the autumns of 1981, 1982, and 1983 to plots not previously fertilized) increased yield with increasing $\mathrm{N}$ rates during the first growing season after $\mathrm{N}$ fertilization (i.e., 1982, 1983, and 1984). On those plots fertilized in October 1981, significant dry matter increases with increased $\mathrm{N}$ rate were noted in 1982 (Fig. 2). However, in 1983 and 1984, increased dry matter production due to carry-over of $\mathrm{N}$ fertilizer was noted only at the $448 \mathrm{~kg} \mathrm{~N} \mathrm{ha}^{-1}$ rate, and no significant response was noted in 1985 or 1986. Similar trends were found in dry matter production on those plots that received single applications of fertilizer $N$ in the falls of 1983 and 1984 (data not shown). On those plots, however, response to fertilizer $\mathrm{N}$ applied at $448 \mathrm{~kg} \mathrm{ha}^{-1}$ carried over only to the second growing season after application.

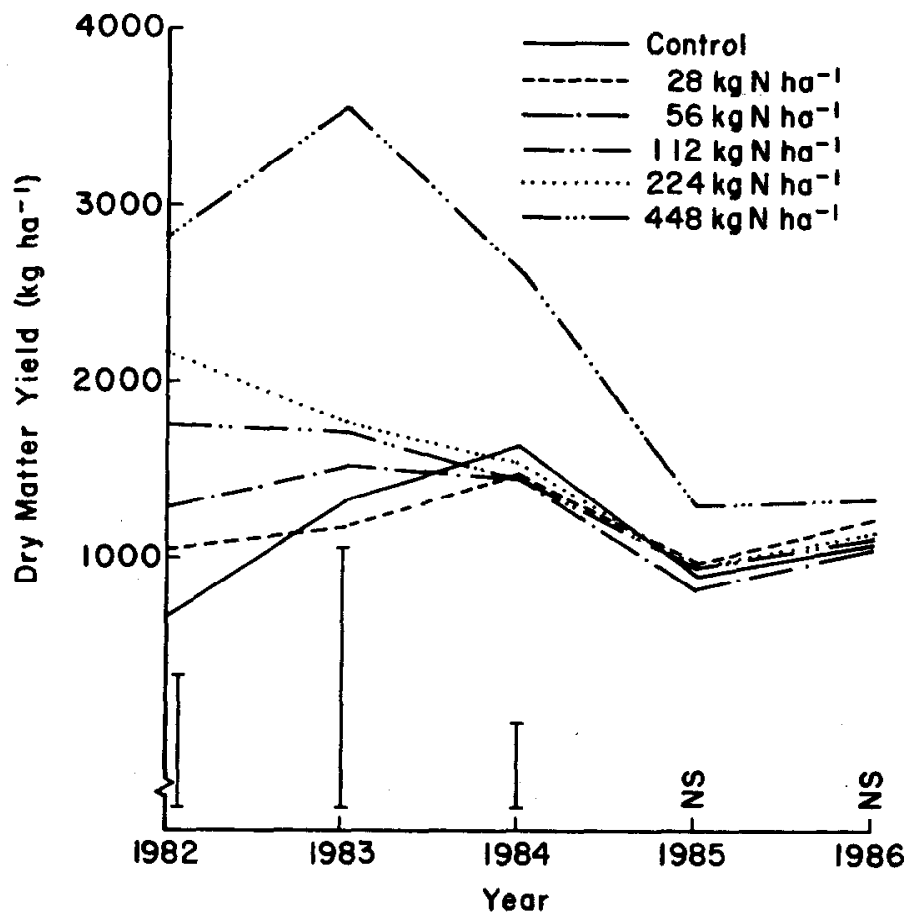

Fig. 2. Dry matter production during a 5 year period as affected by a single application of $0,28,567,112,224$ or $448 \mathrm{~kg} \mathrm{~N} \mathrm{ha}^{-1}$ fertilizer in the fall of 1981. Error bars for 1982, 1983 and 1984 indicate the least significant difference (according to Tukey's $Q$ test) in dry matter production among levels of $N$ applied.
Residual effects of single applications of fertilizer $\mathbf{N}$ on nonmined land forage production have been found to last from 1 to 10 years (McGinnies 1968; Power and Alessi 1971; Wight and Black 1979; Lutwick and Smith 1977, 1979; Rauzi 1979; Read and Winkleman 1982; and White 1985). These studies found that residual response is generally longer for higher $\mathrm{N}$ fertilizer rates, and that no significant carry-over is generally noted at lower rates. Forage yield response is generally greatest the first year after fertilization and gradually decreases with time (Wight and Black 1979). The fact that on our plots forage yield response to residual fertilizer $\mathbf{N}$ declined rapidly and not gradually may be due to 2 factors:

(1) The developing ecosystem on this mined-land is still accumulating biomass and nutrients as it progresses towards a new equilibrium between $\mathrm{N}$ demand and supply. Decades may be required for the root litter and the soil organic matter components to become fully developed and equilibrate, and until these components equilibrate, they act as sinks for $\mathbf{N}$ and deplete the amount of $\mathrm{N}$ available for annual plant growth (Woodmansee et al. 1978).

(2) The potential for nitrate leaching is greater in the mined lands studied here than in many nondisturbed grasslands. Nondisturbed grasslands frequently contain a well developed clayey B horizon with high water holding capacity (Woodmansee 1979). In contrast, the majority of the rooting zone in these mined lands is composed of unconsolidated spoil which has a fairly low water holding capacity (Table 1). Moreover, this disturbed-land ecosystem has probably not yet developed equilibrium levels of plant roots and microorganisms which are capable of extracting nitrate from solution before it leaches below the rooting zone (Woodmansee et al. 1981). Leaching losses of fertilizer ${ }^{15} \mathrm{~N}$ have been measured in other studies conducted on these topsoiled spoil materials (Reeder, unpublished data).

\section{Canopy Cover}

Trends in canopy cover response to fertilizer $\mathbf{N}$ and $\mathbf{P}$ were similar to trends in yield response to fertilizer $\mathbf{N}$ and $\mathrm{P}$. Canopy cover was highly correlated with dry matter production, with correlation coefficients $(r)$ for any year generally greater than 0.95 . Averaged over the 5 years of this study, aerial cover was $16,27,32$, 54 , and $67 \%$ on those plots annually receiving $0,28,56,112$, and $224 \mathrm{~kg} \mathrm{~N} \mathrm{ha}^{-1}$, respectively.

For bond release under current regulations, mining companies must show that dry matter production and aerial cover on reclaimed mined lands are comparable to those on a non-mined reference area. A comparison made in 1982 revealed that aerial cover on the non-fertilized plots was considerably lower (13\%) than that on non-mined reference areas $(80 \%)$. Shrubs (primarily big sagebrush) dominate the non-mined reference areas, contributing $52 \%$ of the cover, whereas grasses and forbs represent $31 \%$ and $17 \%$ of the cover, respectively. Only with the applications of 112 or $224 \mathrm{~kg} \mathrm{~N} \mathrm{ha}^{-1}$ was cover on the research plots comparable to that of the non-mined reference areas.

\section{Species Composition}

Changes in species composition as the result of $\mathbf{P}$ fertilization have been reported for recently seeded mined lands (Halvorson and Bauer 1984). Moderate-to-high rates of fertilizer $N$ have been found to change the composition of mixed species pastures (Power and Alessi 1971, Power 1980a, Halvorson and Bauer 1984). However, during the 5 years of the study reported here, neither $N$ nor $P$ fertilization significantly affected species composition. Vegetation growing on the plots was dominated by smooth brome and intermediate wheatgrass. These 2 species generally comprised over $90 \%$ of the species composition, with averages of $53.4 \%$ for smooth brome and $41.4 \%$ for intermediate wheatgrass. Crested wheat- 
grass, Kentucky bluegrass, and alfalfa accounted for most of the remaining species composition. Western wheatgrass and hard fescue were rarely found in the plots. The lack of a significant response of species composition to fertilizer $\mathbf{N}$ or $\mathbf{P}$ may be due to smilarities between the 2 dominant species in phenology, vigor, and growth response to fertilizer, that are sufficient to preclude differential stimulation.

\section{Crude Protein Concentration of Vegetation}

Crude protein concentration was used as a measure of forage quality. The average crude protein concentration of vegetation harvested from plots receiving no fertilizer was $6.6 \%$, and ranged from $6.1 \%$ in 1986 to $8.8 \%$ in 1983 . Annual application of fertilizer $P$ did not significantly affect the crude protein concentration of harvested forage in any of the 5 years of this study, whereas the effect of annual $\mathrm{N}$ fertilization varied from year to year (Fig. 3). In 3 of the 5 years $(1982,1985,1986)$, crude protein concentration significantly increased only at the 112 and $224 \mathrm{~kg} \mathrm{~N} \mathrm{ha}^{-1}$ rates. In 1983 and 1984, there was no significant effect of fertilizer $N$ on crude protein concentration. The crude protein values in 1983 for the control and for the $56 \mathrm{~kg} \mathrm{~N}^{-1}$ rate were highly variable among replicate plots and were thought to have resulted from harvesting a disproportionate amount of alfalfa during random sampling of some of the plots. The lack of response in 1984 to fertilizer $\mathrm{N}$ may have been due to dilution of crude protein concentration by high dry matter production (Fig. 1).

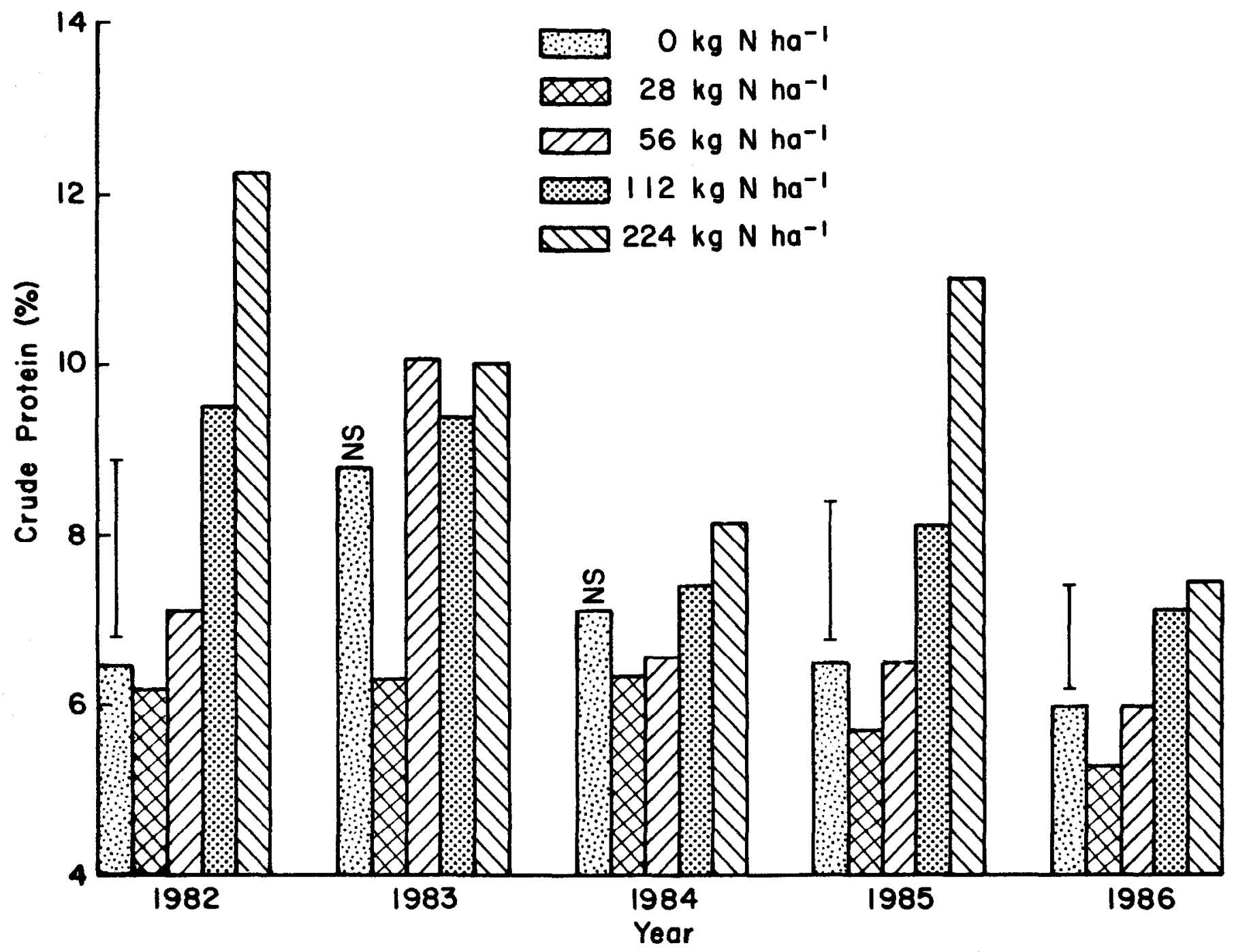

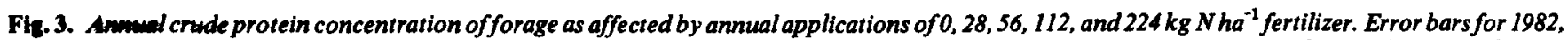
1985 and indicate the least significant difference (according to Tukey's $Q$ test) in crude protein concentration among levels of $N$ applied.

On plots receiving a single application of fertilizer $\mathrm{N}$, the crude protein concentration of harvested forage was significantly affected by $\mathbf{N}$ rate during the first growing season after application. For those plots receiving $N$ in the autumn of 1981 , crude protein concentration varied significantly with $\mathrm{N}$ rate in 1982 and 1983 , the first and second growing seasons after application (Fig. 4). However, by the third growing season, crude protein concentrations were no longer significantly affected by residual fertilizer $\mathbf{N}$. Similar trends were found in the crude protein concentrations of vegetation in plots that received fertilizer $\mathrm{N}$ prior to the 1983 and 1984 growing seasons, except that the effect of fertilizer $N$ on crude protein concentration did not carry over to the second growing season after fertilizer application (data not shown). In comparison, White (1985) found that single applications of low rates of fertilizer $\mathrm{N}$ affected crude protein concentration of western wheatgrass for 6 years after application.

\section{Phosphorus Concentration of Vegetation}

The annual application of fertilizer $P$ significantly increased the $P$ concentration of harvested vegetation. The $P$ concentration of vegetation harvested from control plots averaged $0.160 \%$, as compared to an average $P$ concentration of $0.171 \%$ in vegetation harvested from $P$-fertilized plots. The $P$ concentration of vegetation harvested from the P-fertilized plots did not change significantly from 1982 through 1986. 
For any given year, the $P$ concentration of harvested vegetation was not significantly affected by either annual or single applications of fertilizer $\mathbf{N}$. However, the average $P$ concentration of vegetation harvested from control plots and from $\mathbf{N}$-fertilized plots steadily and significantly declined from $0.178 \%$ in 1982 to $0.146 \%$ in 1986 . The reduction of forage $P$ concentration with $\mathbf{N}$ fertilization may be an indication that the increased plant growth obtained as a result of $\mathrm{N}$ fertilization caused a depletion of the available soil $\mathrm{P}$ as well as the fertilizer P initially applied (Rcad and Winkleman 1982). Other researchers have reported significant decreases in forage $P$ concentration with $N$ fertilization (Black 1968, Black and Wight 1979, Read and Winkleman 1982, White 1985). An explanation for the steady annual decline in forage $P$ concentration from control plots is not apparent since the control plot soil plantavailable $P$ level at the end of this study averaged $12.5 \mathrm{mg} / \mathrm{kg}$, a level which is considered adequate for plant growth (Olsen and Sommers 1982).

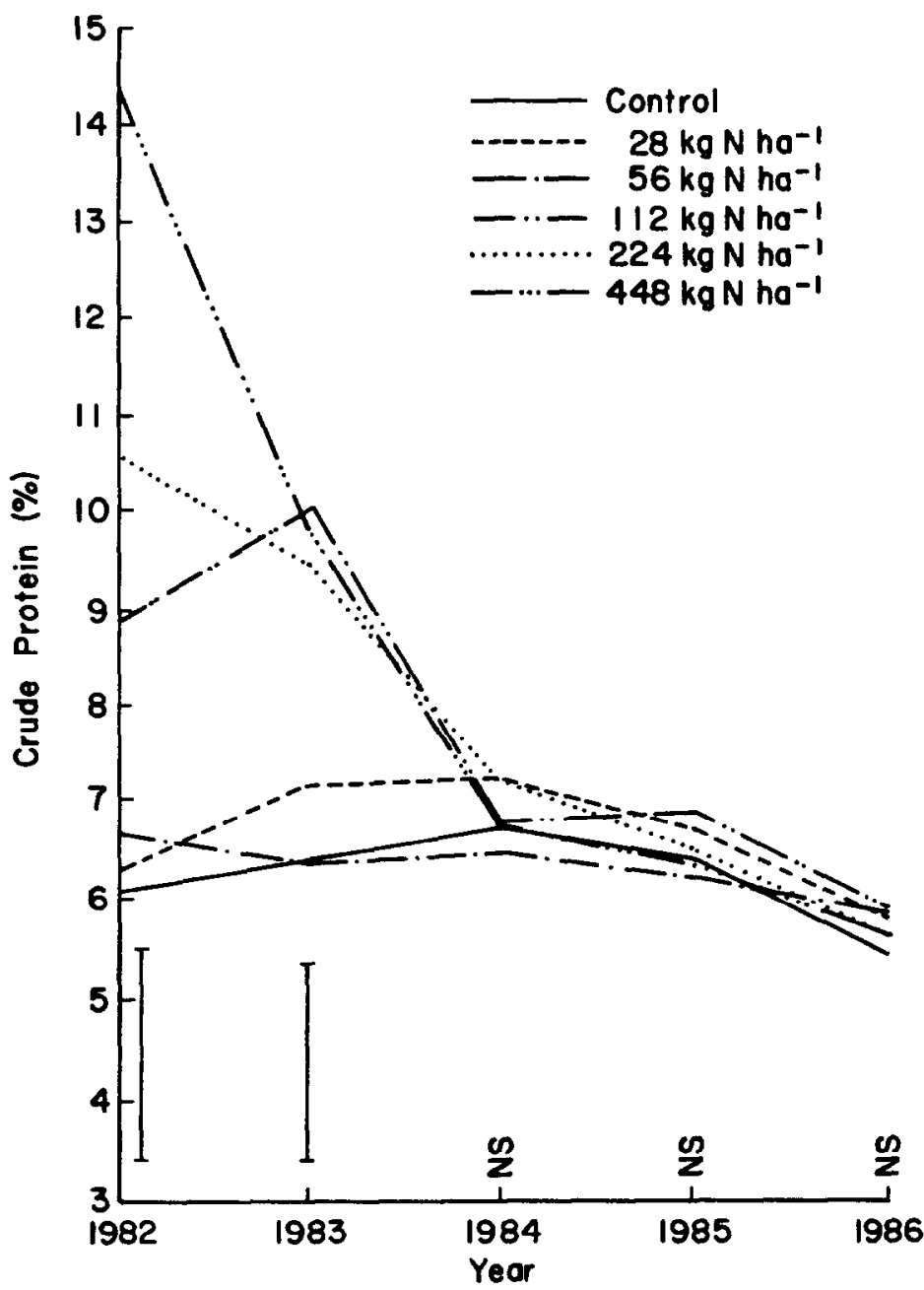

Fig. 4. Crude protein concentration of forage during a five year period as affected by a single application of $0,28,56,112,224$ or $448 \mathrm{~kg} \mathrm{~N} \mathrm{hal}^{1}$ fertilizer in the fall of 1981 . Error bars for 1982 and 1983 indicate the least significant difference (according to Tukey's $Q$ test) in crude protein concentration among levels of $N$ applied.

\section{Conclusions}

The data from this study suggest that although applications of high rates of $\mathbf{N}$ at infrequent intervals would reduce costs of fertilizer handling and distribution, such applications would not improve dry matter production after 2 or 3 growing seasons. Thus annual applications of fertilizer $\mathbf{N}$ on reclaimed mined land would be more effective than infrequent applications of high rates of $\mathbf{N}$. However, under current regulations, annual fertilizer applications are not an acceptable way of meeting reclamation standards for disturbed mined lands. Yet on mined land that has been released from bonding and is to be grazed, the annual application of $\mathrm{N}$ at moderate rates may be justified for increased forage production and protein concentration. On the basis of the results from this study, each pound of $\mathbf{N}$ applied will provide at least 1 day's grazing for a yearling steer. The economic feasibility of applying $\mathbf{N}$ will depend on the cost of the $\mathbf{N}$, the importance of obtaining additional forage, and the cost of getting the additional forage from other sources.

\section{Literature Cited}

Black, A.L. 1968. Nitrogen and phosphorus fertilization for production of crested wheatgrass and native grass in northeastern Montana. Agron. J. 60:213-216.

Black, A.L., and J.R. Wight. 1979. Range fertilization: nitrogen and phosphorus uptake and recovery over time. J. Range Manage. 32:349-353.

Cook, C. Wayne, Robert M. Hyde, and Phillip L. Sims. 1974. Revegetation guidelines for surface mined areas. Science Series No. 16. Range Science Dep., Colorado State Univ., Fort Collins.

Cook, C. Wayne, and Charles D. Bonham. 1977. Techniques for vegetation measurements and analysis for a pre- and post-mining inventory. Science Series No. 28. Range Science Dep., Colorado State Univ., Fort Collins.

Colville, W.L., Leon Chesnin, and D.P. McGill. 1963. Effect of precipitation and long term nitrogen fertilization on nitrogen uptake, crude protein content and yield of bromegrass forage. Agron. J. 55:215-218.

DePuit, E.J., and J.G. Coenenberg. 1979. Responses of revegetated coal strip mine spoils to variable fertilization rates, longevity of fertilization program and season of seeding. Research Report 150. Montana Agricultural Experiment Station, Bozeman.

Doerr, T.B., E.F. Redente, and T.E. Sievers. 1983. Effect of cultural practices on seeded plant communities on intensively disturbed soils. J. Range Manage. 36:423-428.

Donahue, Roy L., Raymond W. Miller, and John C. Shickluna. 1983. Soils, an introduction to soils and plant growth. Prentice-Hall, Inc., Englewood Cliffs, N. J.

Halvorson, G.A., and A. Bauer. 1984. Yield and botanical composition of a grass-legume mixture on reclaimed land as affected by $\mathrm{N}$ and $\mathrm{P}$ fertilizer. Agron. J. 76:355-358.

Johnston, A., S. Smollak, A.D. Smith, and L.E. Lutwick. 1969. Seasonal precipitation, evaporation, soil moisture, and yield of fertilized range vegetation. Can. J. Plant Sci. 49:123-128.

Lutwick, L.E., and A.D. Smith. 1977. Yield and composition of alfalfa and crested wheatgrass grown singly and in mixture, as affected by $\mathrm{N}$ and $\mathrm{P}$ fertilizers. Can. J. Plant Sci. 57:1077-1083.

Lutwick, L.E., and A.D. Smith. 1979. Yield and N uptake by seven perennial grass species as affected by high rates of $\mathbf{N}$ fertilizer. J. Range Manage. 32:433-436.

McGinnies, William J. 1968. Effects of nitrogen fertilizer on an old stand of crested wheatgrass. Agron. J. 60:560-562.

McGinnies, William J., and P.J. Nicholas. 1980. Effects of topsoil thickness and nitrogen fertilizer on the revegetation of coal mine spoils. J. Environ. Qual. 9:681-685.

McGinnies, William J., and K.A. Crofts. 1986. Effects of $N$ and $P$ fertilizer placement on establishment of seeded species on redistributed mine topsoil. J. Range Manage. 39:118-121.

Olsen, S.R., and L.E. Sommers. 1982. Phosphorus. In: A.L. Page et al. (ed.). Methods of Soil Analysis, Part 2. Agronomy 9:403-430. Amer. Soc. Agron. Madison, Wisc.

Power, J.F. 1967. The effect of moisture on fertilizer nitrogen immobilization in grasslands. Soil Sci. Soc. Amer. Proc. 31:223-226.

Power, J.F. 1980a. Response of semiarid grassland sites to nitrogen fertilization: I. Plant growth and water use. Soil Sci. Soc. Amer. J. 44:545-550.

Power, J.F. 1980b. Response of semiarid grassland sites to nitrogen fertilization: II. Fertilizer recovery. Soil Sci. Soc. Amer. J. 44:550-555.

Power, J.F. 1986. Nitrogen cycling in seven cool-season perennial grass species. Agron. J. 78:681-687

Power, J.F., and J. Alessi. 1970. Effects of nitrogen source and phosphorus on crested wheatgrass growth and water use. J. Range Manage. 23:175-178. 
Power, J.F., and J. Alead. 1971. Nitrogen fertilization of semiarid grasslands: Plant growth and soil mineral N levels. Agron. J. 63:277-280.

Rauxi, Frank. 1979. Residual effects of phosphorus and high rates of nitrogen on shortgrass rangeland. J. Range Manage. 32:470-474.

Read, D.W.L., and G.E. Winkleman. 1982. Residual effects of nitrogen and phosphorus fertilizer on crested wheatgrass under semiarid conditions. Can. J. Plant Sci. 62:415-425.

Redente, E.F., T.B. Doerr, C.E. Gry giel, and M.E. Biondini. 1984. Vegetation establishment and succession on disturbed soils in northwest Colorado. Reclam. and Rev. Res. 3:153-165.

Redente, E.F., and N.E. Hargis. 1985. An evaluation of soil thickness and manipulation of soil and spoil for reclaiming mined land in northwest Colorado. Reclam. and Rev. Res. 4:17-29.

Reeder, J.D. 1988. Transformation of nitrogen-15-labeled fertilizer nitrogen and carbon mineralization in incubated coal mine spoils and disturbed soil. J. Environ. Qual. 17:291-298.

Reeder, J.D., and B. Sabey. 1987. Nitrogen. p. 155-184. In: R.D. Williams and G.E. Schuman (ed.) Reclaiming mine soils and overburden in the western United States: Analytic parameters and procedures. Soil Conserv. Soc. Amer.
Smika, D.E., H.J. Haas, and J.F. Power. 1965. Effects of moisture and nitrogen fertilizer on growth and water use by native grass. Agron. J. 57:483-486.

White, L.M. 1985. Long-term residual effects of nitrogen fertilization on western wheatgrass. J. Range Manage. 38:461-466.

Wight, J.R. 1976. Range fertilization in the northern Great Plains. J. Range Manage. 29:180-185.

Wight, J. Ross, and A.L. Black. 1979. Range fertilization: Plant response and water use. J. Range Manage. 32:345-349.

Woodmansee, R.G. 1979. Factors influencing input and output of nitrogen in grasslands. In: N.R. French (ed). Perspectives in Grassland Ecology. Ecol. Studies 32:117-134. Springer-Verlag, New York.

Woodmansee, R.G., J.D. Reeder, and W.A. Berg. 1978. Nitrogen in drastically disturbed lands. p. 376-392. In: C.T. Youngberg (ed) Forest Soils and Land Use. Dep. Forest and Wood Sci., Colorado State Univ., Fort Collins.

Woodmansee, R.G., I. Vallis, and J.J. Mott. 1981. Grassland nitrogen. In: F.E. Clark and T. Rosswall (ed). Terrestrial Nitrogen Cycles. Ecol. Bull. (Stockholm) 33:443-462. 